\title{
Native American Sovereignty and U.S. Citizenship
}

\section{Robert Keith Collins}
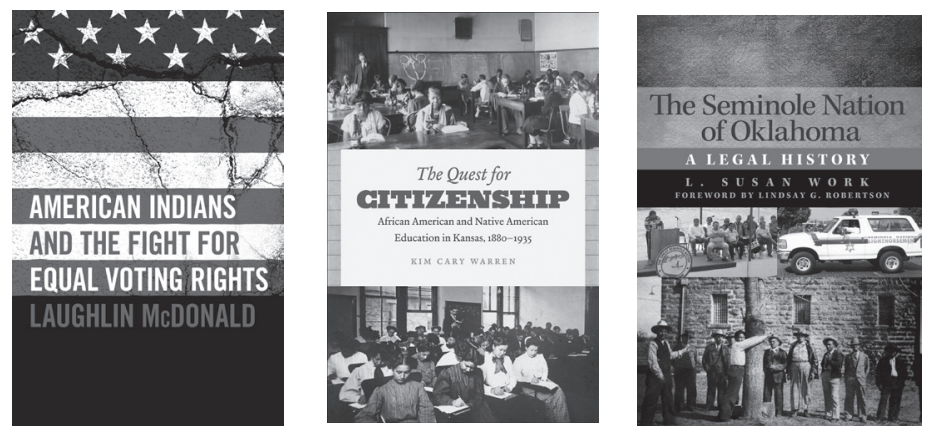

AMERICAN INDIANS AND THE FIGHT FOR EQUAL VOTING RIGHTS. By Laughlin McDonald. Norman, OK: University of Oklahoma Press. 2010. THE QUEST FOR CITIZENSHIP: African American and Native American Education in Kansas, 1880-1935. By Kim Cary Warren. Chapel Hill, NC: University of North Carolina Press. 2010.

THE SEMINOLE NATION OF OKLAHOMA: A Legal History. By L. Susan Work. Norman, OK: University of Oklahoma Press. 2010.

What is the relationship between Native American sovereignty and U.S. citizenship? McDonald's American Indians and The Fight for Equal Rights, Warren's The Quest For Citizenship, and Work's The Seminole Nation of Okla- 


\section{Robert Keith Collins}

homa offer analyses that examine the nature and origins of this relationship, as discernible from legal, historical, and narrative records. These works encourage the reader to consider potential answers to this question from Native American struggles for civil rights as both citizens of sovereign tribal nations and U.S. citizens. A common assertion made by all authors is that this relationship must be understood as a direct precipitate of the struggles for civil rights, voting equality, educational opportunities, and government-to-government relationships that have shaped Native American lived realities from the late nineteenth through the twentieth centuries.

This perennial question may seem to have been exhausted; however, it is only because American studies of this relationship have historically centered on what the United States did to Native Americans, rather than the agency demonstrated by the people both individually and collectively. Contrary to this approach, McDonald, Warren, and Work focus on what Native Americans did in the face of assimilation, cultural change, discrimination in voting, and legislative efforts to influence tribal sovereignty. Their research illustrates, on the one hand, that to understand this relationship, the experiences and interactions between Native Americans (e.g., Crow, Gros Ventre, Seminole, Sioux, etc.) and the legislators, missionaries, stakeholders, and teachers must be chronicled; however, on the other hand, the active negotiation - not passive reception-Native Americans participated in during these interactions and the formulation of their civil rights and identities as citizens of both sovereign tribal nations and the United States must also be examined. Knowing that Native Americans have experienced discrimination as U.S. citizens is only the beginning. There remains that challenge of examining when, where, and in which contexts this suppression of civil rights has occurred and how Native self-deterministic resistance facilitated their struggles for equality.

This approach taken by the authors is particularly timely, as comparative American studies of Native American civil rights struggles with those of other ethnic minorities (e.g., African Americans) in the U.S. are expanding. No longer is the federal government the sole central focus in analyses of discrimination against Native Americans. Instead, as discussed in all three books, the differences, similarities, and elusive complexities of federal policy towards Native Americans are now being analyzed in tandem with the discrimination that some social and political interactions between Native Americans and non-Natives have produced (e.g., racial polarization in voting, contempt for non-taxation of Native Americans, etc.). Such analyses illuminate the duality of Native American civic existence through an emphasis on the uniqueness of contradictory federal and state policies - as well as social customs - towards Native American sovereignty, while illuminating the struggles for civil rights Native Americans share in common with other U.S. citizens that continue to fight for social equality.

This discourse, premised on the review of primary documentation, offers irrefutable data supporting the notion that federal and state policies were not dictators of the parameters of Native American civic engagement, resistance to 
discrimination in educational opportunities, and expressions of tribal sovereignty. Collectively, McDonald, Warren, and Work's books remind the reader that federal and state laws on Native American voting, education, and nations building were very specific and followed; however, there were enough communities and individuals who found these laws insufficient, challenged their implementation, and sought reform.

McDonald's American Indians and the Fight for Equal Voting Rights engages the significance of these points by examining how citizens of the Crow, Northern Cheyenne, Omaha, Salish - Kootenai, Utes, and other nations have been disentitled from the right to vote in the states of Colorado, Montana, Nebraska, South Dakota, and Wyoming. Through nine highly informative chapters, which focus on litigation filed since the 1980s, the author thoroughly investigates the legal efforts aimed at improving Native American voting rights brought forth by the American Civil Liberties Union (ACLU) Voting Rights Project.

Following a brief introduction that explains the format of the book, the rationale behind the legal historical approach taken, and the implications this approach holds for understanding the lingering impact of historical voting discrimination in the present, the first chapter provides readers with a comprehensive examination of the creation and maintenance of U.S. policies regarding Native Americans from the 1820s through 2008. This discussion centers on the limited and inconsistent salience of the U.S. Constitution and federal policies in Native American civic lives over time. One set of laws - reinforced by subsequent state specific laws and social customs - facilitated the assimilation of Native Americans through the removal of nations from their original homelands, the allotment of tribal lands, the selling of surplus lands to white Americans, the granting of U.S. citizenship to Native Americans, and the suppression of tribal life ways. Another set of laws maintained the reservation system, treaty rights, protects tribal nations as self-governing bodies, and granted religious freedom, while allowing states to assume jurisdiction over tribal lands and-in some cases, as in Wyoming and the Ward v. Race Horse case - trump treaty rights with state law (12).

Although the linkage between chapter 1 and chapter 2 is slightly illusive, the second chapter, examines The Voting Rights Act of 1965, its function (i.e., prohibiting discrimination on the basis of skin color) for Native American individuals and nations, the similarities and differences in application towards racial groups (e.g., African Americans), and its expansion in 1975 to include "language minorities," which also included Native Americans and Alaskan Natives, Asian Americans, Latinos, and immigrants (35). McDonald makes it clear from Senate reports and testimony that Native Americans have experienced as much discrimination and encroachment upon their voting rights as other minorities in the United States. Despite the granting of U.S. citizenship to Native Americans in 1924, the upholding of Native Americans and Alaskan Natives as entitled to protection under the Fourteenth Amendment-as late as 1948-Native Americans have been systematically refused the right to vote, had their vote suppressed through racial bloc voting by whites, and found themselves the 


\section{Robert Keith Collins}

victims of county redistricting to limit their voting power well into the present. All of these phenomena are meticulously explained with context-specific details in chapters three through eight.

Of particular importance in the second chapter, however, is the evolution of this act and its further expansion in 1982, 1992, and 2006 to address persistent discrimination in voting against racial and language minorities, particularly Native Americans, which coincided with their growing political participation. Included in this expansion were provisions requiring plaintiffs to prove racial discrimination in practice. Such proof took the form of court decisions acknowledging discriminatory practices against Native Americans. For example, in the Oregon v. Mitchell case, literacy tests were proven to be a weapon-also used against African Americans - to suppress the Native American vote.

Chapter 3, the first of six comprehensive chapters that illuminate the challenges against voting discrimination brought by Native Americans in Montana, South Dakota, Colorado, Nebraska, and Wyoming, examines the first lawsuits (e.g., Windy Boy v. Country of Big Horn) in Indian Country brought by the Crow and Northern Cheyenne with the representation of the ACLU. It chronicles the history of discrimination against Native Americans and presents the reader with examples of the dynamics of anti-Native American prejudice, as discernable from individual remembered experiences. Such narratives offer the reader a chance to understand how Crow, Northern Cheyenne, Salish, and Kootenai individuals made sense of white prejudices and their motivations for resistance. Their stories reflect understandings of local race cultures that forbid interracial dating, but also political arenas where white racial bloc voting was championed in order to prevent Native Americans from holding office. Why Native Americans used this same strategy to ensure the election of Native American representationfrom majority-Native American districts - onto the Big Horn County Board of Commissioners and school boards of Rosebud and Roosevelt counties, etc. is also discussed.

Although the subsequent chapters examine these discrimination phenomena in other states, it is McDonald's concluding chapters that enlightens and solidifies for the reader the rationale behind the book: the growing importance of the Native American vote. This enlightening chapter reviews how state and federal definitions of citizen voting rights frequently excluded Native Americans, much as they once excluded African Americans, and encourages the reader to question the implications that Native Americans challenging voting discrimination over time hold for the growing importance of the Native American vote in state politics that surround their tribal communities. As tribal nations expand in population and their citizenry begin to exercise collective voting power and actualize their self-determination efforts, their impact can only continue to develop in ways that enrich tribal sovereignty and expand the roles that they continue to play as citizens of the United States.

The larger issue of the relationship between Native American sovereignty and U.S. citizenship is central in Warren's The Quest for Citizenship: African 
American and Native American Education in Kansas, 1880-1935: How have Native Americans thought of themselves as Americans? This question is central because it further illuminates the duality of Native American existence within the United States: being citizens of sovereign tribal governments and belonging to the larger citizen population of the U.S. nation state. While McDonald's work reveals the struggles that Native Americans have endured to find meaning - and cultivate a formidable presence - through civic engagement, Warren's The Quest for Citizenship: African American and Native American Education in Kansas, 1880-1935 examines similar reactions and struggles by Native Americans in the educational arena and their similarities and differences to those of African Americans. The focal point of this analysis is premised on three questions: "How did blacks and Indians think of themselves as Americans? How did their notions of citizenship get influenced or crafted by white reformers in schools? How did these two groups define American citizenship for themselves despite whites' efforts to dictate those definitions" (5-6).

Warren addresses these questions through a lens of cultural citizenship, which comparatively engages the extent to which education in Kansas was effective in conveying an identity of belonging within the United States to African American and Native American students. Divided into three parts, this book introduces six comprehensive chapters and a brief conclusion aimed at illuminating how government officials, missionaries, and teachers acculturated African American and Native American students into America's racial divide - as well as racially assigned social roles - through segregated education. For Native Americans, this would mean separation from tribal communities, acquisition of the English language and "civilized" manners associated with citizenship, preparation for transitioning into public schools with white students, and possible intermarriage into white society. Similarly, African Americans were to be taught citizenship, however, their contributions were to be through labor and lives kept separate from-but in service of - white society.

Despite these goals that directed the processes of acculturation for both populations, Warren argues, Native Americans and African Americans found the means to resist these prescribed social roles and cultivate their own identities and senses of belonging as Americans through education. Following a thorough introduction, which explains the author's rationale for the book, approach taken, usage of terms, and chapter organization, chapter one presents a straightforward discussion of "Reformer" discourse: questions raised by educators and other stakeholders seeking to solve the "Negro Problem" and "Indian Problem" (13). Warren gives particular attention to the efforts and questions of Elizabeth Comstock and Hervey Peairs, making an important distinction between their intentions and their actions, which often reinforced the racist notions of inferiority and incompetence that Native American and African American students were supposed to transcend. She asserts that reformer pedagogy furthered colonialism within the classroom by not teaching students about their own histories and importance of their origins within the scope of overall human history. Instead, 
such pedagogy indoctrinated students into rejection of their ancestral life ways and pasts and prepared them to reinforce the social roles white Kansan society expected them to fill. These points, while poignant and thought provoking, require more context-specific examples and explanations of the student-teacher relationships in Kansas classrooms to support them, than is given.

Warren makes up for this, however, in chapter three with an assiduous examination of Native American student navigations and negotiations of the curriculum at Haskell Institute and the limited nature of parental input into pedagogy due to the distance between the schools and tribal communities. This point is juxtaposed with the relatively active parental involvement seen in the education of African Americans in the fourth chapter. She asserts that student strategies for navigation and negotiation included compromise, acts of active resistance (e.g., smoking, stealing food, running away, etc.), and passive resistance (e.g., cultural exchange between students from different tribal nations, doing chores slowly, holding on to traditional values such as sharing with one another, etc.). These discussions are detailed enough that the reader can not only gauge the similarities and differences in experiences according to gender, but also the similarities and differences between their experiences with those of African Americans.

Warren's primary discussion in the following chapter centers on how the collective challenge that Africans American adults (e.g., William Vernon, Booker T. Washington, members of the NAACP, the Conventions of Colored Men, et al.) brought against substandard education enabled greater parental input into school curricula in Kansas than afforded Native American parents. The author does not gloss over the prevalence of segregation in Kansas schools serving African Americans. Yet by not doing so, she illuminates how this marginalization - wedded with active collective resistance-leads to African Americans developing new curricula in segregated schools that moved beyond industrial training and service to preparing students for college, professional jobs, and lives more prosperous than the service roles (e.g., house servant, cook, field hand, etc.) prescribed by white Kansan social custom.

Chapter five illustrates how students, emulating and inspired by such efforts, became teachers themselves and carried on this resistance within the classroom and in the face of school boards and funders that continued to insist on industrial service for African Americans. Both chapters are very deft at describing to the reader how many of the stakeholders who sought to transform African American and Native American students failed to address the underlining barrier to the cultivation of a sense of being American and belonging for both populations: socially constructed and customarily reinforced racial hierarchies.

Warren's book concludes with an intriguing discussion of the American identities cultivated by Native American students. Like the previous chapter the reader is offered a glimpse into the motivational lives of former students turned educators (e.g., Ella Deloria and Henry Roe Cloud) who used their education to analyze, give relevance and importance, and ultimately revitalize the same nations and traditional life ways that their educators sought to degrade and eradicate. 
Warren wants the reader to grasp how these efforts ignited the flames of the civil rights movements that both groups would later champion, according to their own desired - self-determined - goals and participatory roles as U.S. citizens.

Susan Work's The Seminole Nation of Oklahoma: A Legal History offers a unique perspective that contextually highlights the importance of sovereignty in this discussion of its relationship to U.S. citizenship. Drawing on three decades of experience as an Oklahoma attorney, this legal history presents a comprehensive review of twentieth-century legislation, policies, and rulings (i.e., Supreme Court decisions) that have shaped the creation and maintenance of the Seminole Nation of Oklahoma. Preceded by a brief introduction that discusses the author's motivations for the book and understandings of the legislation to be presented in subsequent sections, the first chapter examines the federal laws that governed nineteenth-century Indian Territory. Work asserts that the endurance of the Seminole Nation of Oklahoma in the twentieth century cannot be understood without understanding the direct responses the nation gave to imposed federal laws during the previous century. This section reviews the compacts and rulings (e.g., Worchester v. Georgia, the Treaty of 1845 which allowed the Seminoles to settle away from the Creek, the Curtis Act, etc.) that affected the Seminole, as one of the relocated "Five Civilized Tribes."

Chapter two chronicles the roles that the Seminole Allotment Act played in how the Seminole Nation would experience Oklahoma statehood and the dynamics of their interactions with non-Native American populations. Central in this historical discussion are the provisions associated with Seminole allotment, the tribal divisions it created (e.g., anti-principal chief factions, Citizens by blood, Freedmen, and non-Indian tribal citizens), the functions of citizenship roles in the distribution of lands, the Five Tribes Act, and the Enabling Act in its execution. Work compels the reader to understanding this transfer of land-from collective tribal control to individual title - as the negation of treaty guarantees to tribal ownership of property that occurred as non-Native American immigrants sought to own land in what was becoming the state of Oklahoma.

Focusing on the fortitude that language (Mvskoke), religion, and recreation (e.g., stickball) provided the Seminole people, chapter five discusses how Seminole citizens and government were able to weather this encroachment and persevere in cultural and governmental operations before and after statehood. This strength enabled the Seminole government to remain relatively self-sufficient through statehood; however, actions by Congress in 1916 instigated dependency - which furthered dissent within the nations - when Congress passed a provision that tribal funds could not be spent by the Five Civilized Tribes without congressional appropriations (i.e., except on per capita payments, specific attorney contracts, tribal schools, etc.). Similar acts, in succession, would further facilitate Seminole dependency on the U.S. government and give the federal government increasing influence over Seminole economic and governmental affairs through the late 1960s. 
The epilogue that concludes this resource-rich legal history encourages the reader to develop an appreciation for how this past motivated Seminole self-determination efforts. These included — but were not limited to - increased self-reliance and a more integral role within Oklahoma, specifically Seminole County: the establishment of a county-wide road works program, public transit system, Older American Program, and other support services for both tribal citizens and the county at large.

What implications do these texts hold for understanding the relationship between Native American sovereignty and U.S. citizenship? These books illuminate how Native American agency and self-determination has actively shaped this relationship in American civic and educational arenas. The negation of this agency has been both an intended and unintended byproduct of the processes of Native American acculturation into U.S. citizenship. The works of McDonald, Warren, and Work remind the reader that perhaps if the navigation strategies that Native Americans - like African Americans and other minorities - used to negotiate their U.S. citizenship are to be understood, then the effective civic and educational actions the people engaged in to protect their civil rights must be further examined. Students and scholars of American studies of history should find these resource-dense texts an encouraging foundation for future examinations of this relationship and how individual agency and collective sovereignty has shaped the dynamic salience of U.S. citizenship in American Indian lives. 